\title{
Biophysical and serological characterization of rhabdovirus 903/87 isolated from European lake trout Salmo trutta lacustris
}

\author{
H. V. Björklund ${ }^{*}$, N. J. Olesen, P. E. V. Jørgensen \\ National Veterinary Laboratory, Hangøvej 2, DK-8200 Århus N, Denmark
}

\begin{abstract}
Rhabdovirus 903/87 isolated from European lake trout Salmo trutta lacustris (L.) in Finland was compared serologically with 11 previously reported fish rhabdoviruses. By immunofluorescence, the virus was not related to 9 of these rhabdoviruses; however, the lake trout rhabdovirus 903/87 was serologically related to perch rhabdovirus and pike rhabdovirus DK 5533. Electron microscopic examination showed the virus to be bullet-shaped, with dimensions of $156 \times 65 \mathrm{~nm}$. SDS-PAGE analyses of the structural proteins indicated that the virus belonged to the Vesiculovirus genus of the family Rhabdoviridae, but that the relative mobilities of the glycoprotein and the phosphoprotein (also termed $\mathrm{N}_{s}$ ) could be used to differentiate the $903 / 87$ isolate from the perch rhabdovirus and the pike rhabdovirus DK 5533. The rhabdovirus $903 / 87$ appears to be a new pathogen of fish and we suggest that it be renamed the European lake trout rhabdovirus.
\end{abstract}

KEY WORDS: Virus - Rhabdovirus - Vesiculovirus Fish

\section{INTRODUCTION}

A rhabdovirus was recently isolated from diseased European lake trout Salmo trutta lacustris (L.) in a fish farm in northern Finland. The virus has been preliminarily characterized by Koski et al. (1992) under the designation 'virus 903/87'. In neutralization tests and enzyme-linked immunosorbent assays (ELISA) the virus showed no antigenic relatedness to viral haemorrhagic septicaemia virus (VHSV), infectious haematopoietic necrosis virus (IHNV), spring viraemia of carp virus (SVCV), pike fry rhabdovirus (PFR), European eel rhabdovirus (EVEX) or perch rhabdovirus (Koski et al. 1992).

The aim of the present work was to further characterize this new virus by comparing it with the abovementioned viruses and 5 other previously described fish rhabdoviruses using immunofluorescence tests, and to determine some biophysical properties of the virus.

\footnotetext{
- Present address: Institute of Parasitology, Äbo Akademi University, BioCity, Artillerigatan 6, SF-20520 Åbo, Finland
}

\section{MATERIALS AND METHODS}

Viruses and antisera. The rhabdoviruses included in this study were VHSV, IHNV, hirame rhabdovirus (HRV), snakehead rhabdovirus (SHRV), carpione brown trout rhabdovirus, SVCV, PFR, EVEX, perch rhabdovirus, ulcerative disease rhabdovirus (UDRV), pike rhabdovirus DK 5533, and lake trout rhabdovirus 903/87 (Table 1). The viruses were propagated in cell cultures as described below and those used for immunization of rabbits were purified by ultracentrifugation on 15 to $45 \%$ linear sucrose gradients for $2.5 \mathrm{~h}$ at $27000 \mathrm{rpm}(100000 \times g)$ in a Beckman SW 28 rotor. Rabbit antisera to the viruses were prepared as previously described (Jørgensen et al. 1989, Olesen et al. 1991). Antisera to some of the viruses were obtained from other laboratories (Table 1). Antisera which showed background staining in immunofluorescence were purified using affinity chromatography on Protein A-Sepharose (Pharmacia, Uppsala, Sweden) and absorbed with cell culture cells as described by Jørgensen et al. (1993).

Fish cell lines and medium. Monolayer cultures of bluegill fry cells, BF-2 (Wolf et al. 1966) and epithe- 
Table 1 Virus isolates and antisera used

\begin{tabular}{|c|c|c|c|c|c|}
\hline Virus name & Virus strain & Strain isolated from & Supplier of virus $S$ & Supplier of serum & Reference \\
\hline $\begin{array}{l}\text { Viral haemorrhagic } \\
\text { septicaemia virus }\end{array}$ & VHSV, F1 & $\begin{array}{l}\text { Rainbow trout } \\
\text { Oncorhynchus mykiss }\end{array}$ & NVL' & NVL & Jensen (1965) \\
\hline $\begin{array}{l}\text { Infectious haemato- } \\
\text { poietic necrosis virus }\end{array}$ & IHNV, Coleman & $\begin{array}{l}\text { Chinook salmon } \\
\text { Oncorhynchus tshawytscha }\end{array}$ & Wolf, $K$ & NVL & Amend et al. (1969) \\
\hline Hirame rhabdovirus & $\mathrm{HRV}, 8401 \mathrm{H}$ & $\begin{array}{l}\text { Japanese flounder } \\
\text { Paralichthys olivaceus }\end{array}$ & Kimura, $\mathrm{T}$. & Kimura, T & Kimura et al. (1986) \\
\hline $\begin{array}{l}\text { Snakehead } \\
\text { rhabdovirus }\end{array}$ & SHRV & $\begin{array}{l}\text { Snakehead } \\
\text { Ophiocephalus striatus }\end{array}$ & Wattanavijarn, W. & NVL & Ahne et al. (1988) \\
\hline $\begin{array}{l}\text { Carpione brown } \\
\text { trout rhabdovirus }\end{array}$ & 583 & $\begin{array}{l}\text { Carpione brown trout } \\
\text { Salmo trutta carpione }\end{array}$ & Bovo, G. & Bovo, G. & Bovo et al. (unpubl.) \\
\hline $\begin{array}{l}\text { Spring viraemia of } \\
\text { carp virus }\end{array}$ & SVCV, $56 / 80$ & $\begin{array}{l}\text { Common carp } \\
\text { Cyprinus carpio }\end{array}$ & Fijan, N. & NVL & Fijan et al. (1971) \\
\hline $\begin{array}{l}\text { Pike fry } \\
\text { rhabdovirus }\end{array}$ & PFR & $\begin{array}{l}\text { Northern pike } \\
\text { Esox lucius }\end{array}$ & de Kinkelin, P & NVI & de Kinkelin et al. (1973) \\
\hline Eel rhabdovirus & EVEX & $\begin{array}{l}\text { European eel } \\
\text { Anguilla anguilla }\end{array}$ & Castric, J. & NVL & Castric et al. (1984) \\
\hline Perch rhabdovirus & $\begin{array}{l}\text { No strain } \\
\text { designation }\end{array}$ & $\begin{array}{l}\text { Perch } \\
\text { Perca fluviatilis }\end{array}$ & de Kinkelin, $P$ & NVL & Dorson et al. (1984) \\
\hline $\begin{array}{l}\text { Ulcerative disease } \\
\text { rhabdovirus }\end{array}$ & UDRV 19 & $\begin{array}{l}\text { Snakehead } \\
\text { Ophiocephalus striatus }\end{array}$ & Hill, B. & Hill, B. & Frerichs et al. (1986) \\
\hline Pike rhabdovirus & DK 5533 & $\begin{array}{l}\text { Northern pike } \\
\text { Esox lucius }\end{array}$ & NVL & NVL & Jørgensen et al. (1993) \\
\hline $\begin{array}{l}\text { Lake trout } \\
\text { rhabdovirus }\end{array}$ & $903 / 87$ & $\begin{array}{l}\text { European lake trout } \\
\text { Salmo trutta lacustris }\end{array}$ & Neuvonen, E. & NVL & Koski et al. (1992) \\
\hline
\end{tabular}

lioma papulosum cyprini cells, EPC (Fijan et al. 1983) were grown at $15^{\circ} \mathrm{C}$ in Eagle's minimum essential medium (MEM) supplemented with $10 \%$ fetal bovine serum, penicillin $\left(100 \mathrm{IU} \mathrm{ml}^{-1}\right)$ and dihydrostreptomycin $\left(125 \mu \mathrm{g} \mathrm{ml}^{-1}\right)$. Medium for cells grown in open systems (24- or 96-well plates and petri dishes) was buffered with Tris- $\mathrm{HCl}$ buffer while that used for cells grown in tissue culture flasks was buffered with sodium bicarbonate.

Electron microscopy. Monolayer cultures of BF-2 cells were infected with trout rhabdovirus 903/87 at a low multiplicity of infection (MOI 0.1) and incubated at $15^{\circ} \mathrm{C}$. After $24 \mathrm{~h}$ and $48 \mathrm{~h}$ incubation, cells were fixed with $2.5 \%$ glutaraldehyde in $0.07 \mathrm{M}$ phosphatebuffered saline (PBS) ( $\mathrm{pH} 7.6$ ). The cells were postfixed with $1 \%$ osmium tetroxide $\left(\mathrm{OsO}_{4}\right)$ in $0.1 \mathrm{M}$ cacodylate buffer, dehydrated in acetone series and embedded in Epon. Ultrathin sections were stained with uranyl acetate and lead citrate and examined in a JEOL JEM100SX electron microscope. A culture of noninfected BF- 2 cells was included as a control.

Immunofluorescence tests. Monolayer cultures of EPC cells were grown on $9 \times 22 \mathrm{~mm}$ coverglasses and infected with each of the 12 rhabdoviruses. At $24 \mathrm{~h}$ after infection (or $96 \mathrm{~h}$ after infection in the case of UDRV), the cultures were rinsed twice in MEM without fetal bovine serum and fixed for $10 \mathrm{~min}$ in $80 \%$ aqueous acetone. After air-drying, the coverglasses were overlaid with $30 \mu \mathrm{l}$ of homologous or heterologous rabbit antiserum at predetermined dilutions (1:25 to $1: 800)$ in MEM containing $10 \%$ fetal bovine serum. The coverglasses were incubated for $30 \mathrm{~min}$ at $37^{\circ} \mathrm{C}$ in a humid chamber, rinsed twice for $10 \mathrm{~min}$ in $0.9 \% \mathrm{NaCl}$ with $0.05 \%$ Tween 20 , rinsed once for $10 \mathrm{~min}$ in deionized water with $0.05 \%$ Tween 20, air-dried, and overlaid with $30 \mu \mathrm{l}$ of a $1: 100$ dilution of tetramethyl rhodamine isothiocyanate (TRITC) labelled swine antibody to rabbit Ig (Dakopatts, Copenhagen, Denmark). After incubation for $30 \mathrm{~min}$ at $37^{\circ} \mathrm{C}$, the rinse cycles were repeated and the coverglasses were mounted on microscope slides with cell side down in a drop of buffered glycerol, $\mathrm{pH}$ 7.6, and examined with an Olympus Vanox epifluorescence microscope equipped with a $200 \mathrm{~W}$ mercury lamp and 40x and 100x fluorescence oil objectives

Sodium dodecyl sulphate polyacrylamide gel electrophoresis (SDS-PAGE). SDS-PAGE was performed according to the method described by Laemmli (1970) using $0.75 \mathrm{~mm}$ slab gels in a vertical elec- 
trophoresis system. Purified viruses were mixed with tracking dye (bromphenol blue) and sample buffer $10.01 \mathrm{M}$ Tris- $\mathrm{HCl}, \mathrm{pH} \quad 6.8 ; \quad 0.001 \mathrm{M}$ EDTA; $10 \%$ SDS; $5 \% 2$-mercaptoethanol) and heated to $100^{\circ} \mathrm{C}$ for $3 \mathrm{~min}$. Electrophoresis of virus proteins was performed using $13 \%$ acrylamide separating gels overlaid with $3.5 \%$ acrylamide stacking gels. After electrophoretic separation the gels were stained with silver nitrate as described by Morrissey (1981). The molecular weights of the viral structural proteins were estimated by comparing their relative mobilities with those of molecular weight protein standards (Pharmacia, Uppsala, Sweden).

\section{RESULTS}

\section{Cytopathic effect}

Cytopathic effects, consisting of granular, rounded and eventually lysed cells, were typically observed 2 to $3 \mathrm{~d}$ after infection of BF-2 cells with the new rhabdovirus $903 / 87$. The cytopathic effects progressed over a 3 to $4 \mathrm{~d}$ period until the monolayer was destroyed. The virus 903/87 did not induce cytopathic effects in EPC cells, although multiplication occurred, as evidenced by the immunofluorescence results.

\section{Electron microscopy}

Bullet-shaped virus particles were seen in electron micrographs of BF-2 cultures infected with the lake trout rhabdovirus 903/87 (Fig. 1). No virus replication was seen in cells fixed $24 \mathrm{~h}$ after infection, whereas numerous virus-releasing cells were seen in samples fixed $48 \mathrm{~h}$ after infection. Based on measurements of 20 particles, the mean length of the virion was $156 \pm$ $18 \mathrm{~nm}$ and the mean diameter was $65 \pm 4 \mathrm{~nm}$. The minimum and maximum lengths observed were 140 and $210 \mathrm{~nm}$, and the minimum and maximum diameters were 60 and $70 \mathrm{~nm}$.

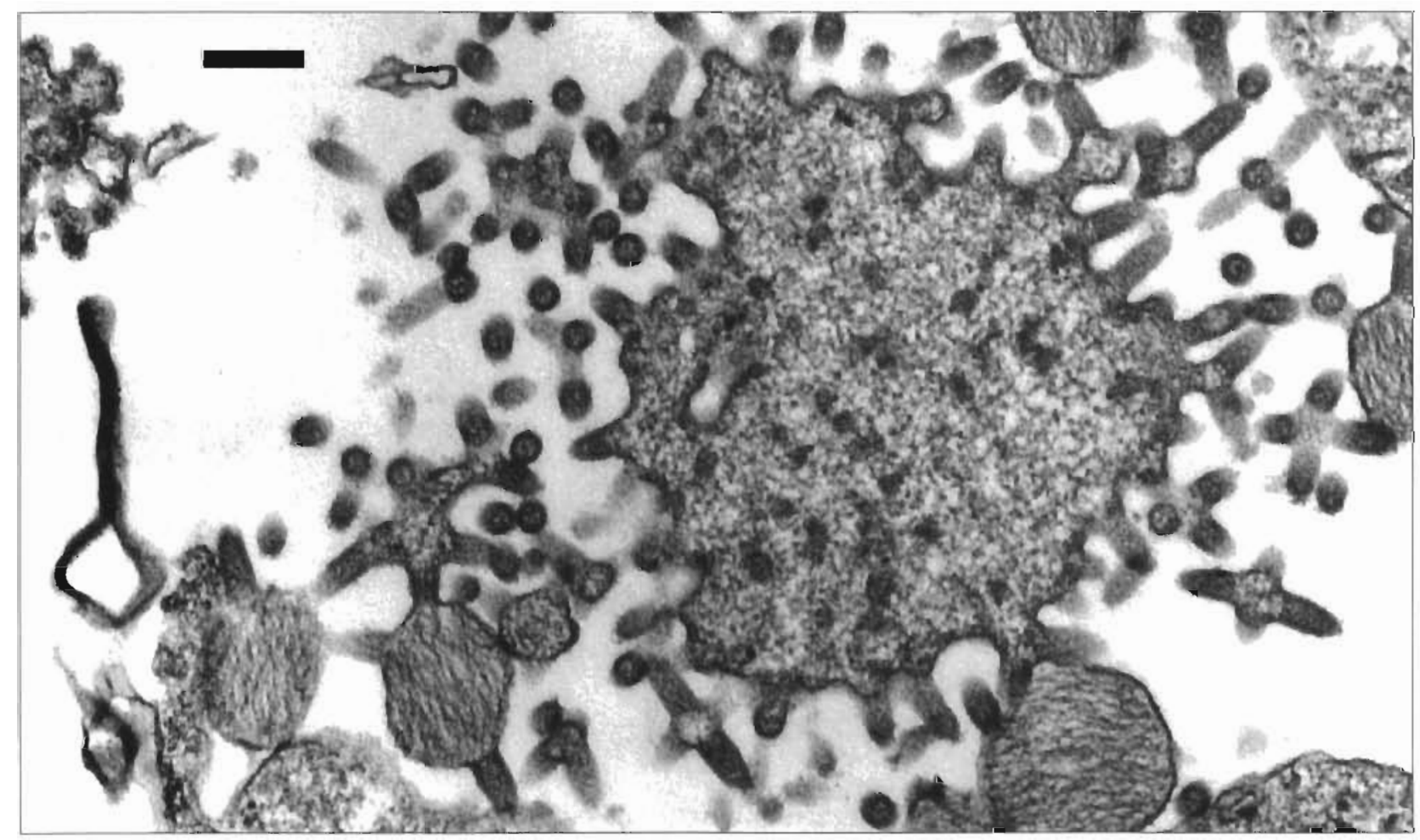

Fig. 1. Electron micrograph showing bullet-shaped virus particles in BF-2 cells infected with lake trout rhabdovirus $903 / 87$. Stained with uranyl acetate and lead citrate (scale bar $=200 \mathrm{~nm}$ ) 


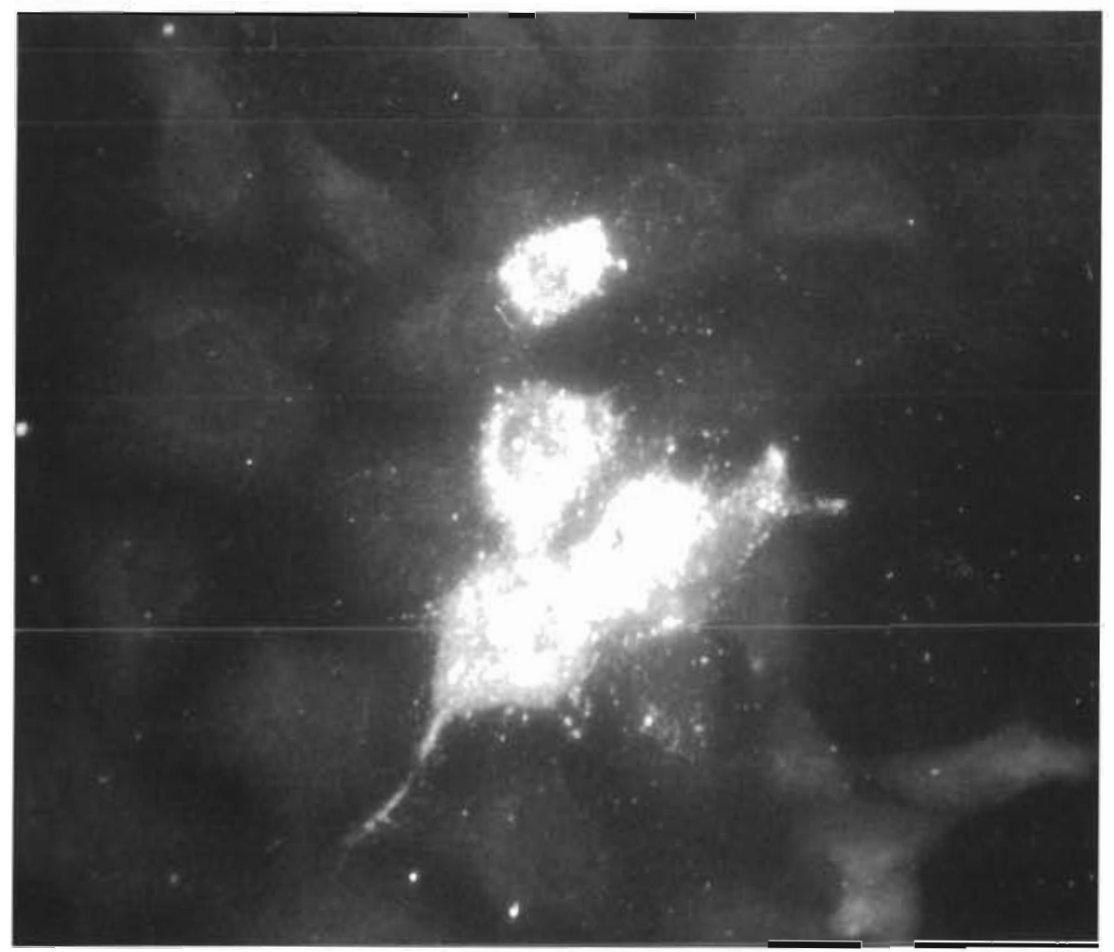

Fig. 2. Immunofluorescence micrograph showing the staining of lake trout rhabdovirus $903 / 87$-infected EPC cells with rabbit antiserum to virus $903 / 87$ as the primary antibody and TRITC-labelled swine antibody to rabbit Ig as the secondary antibody $(\times 370)$

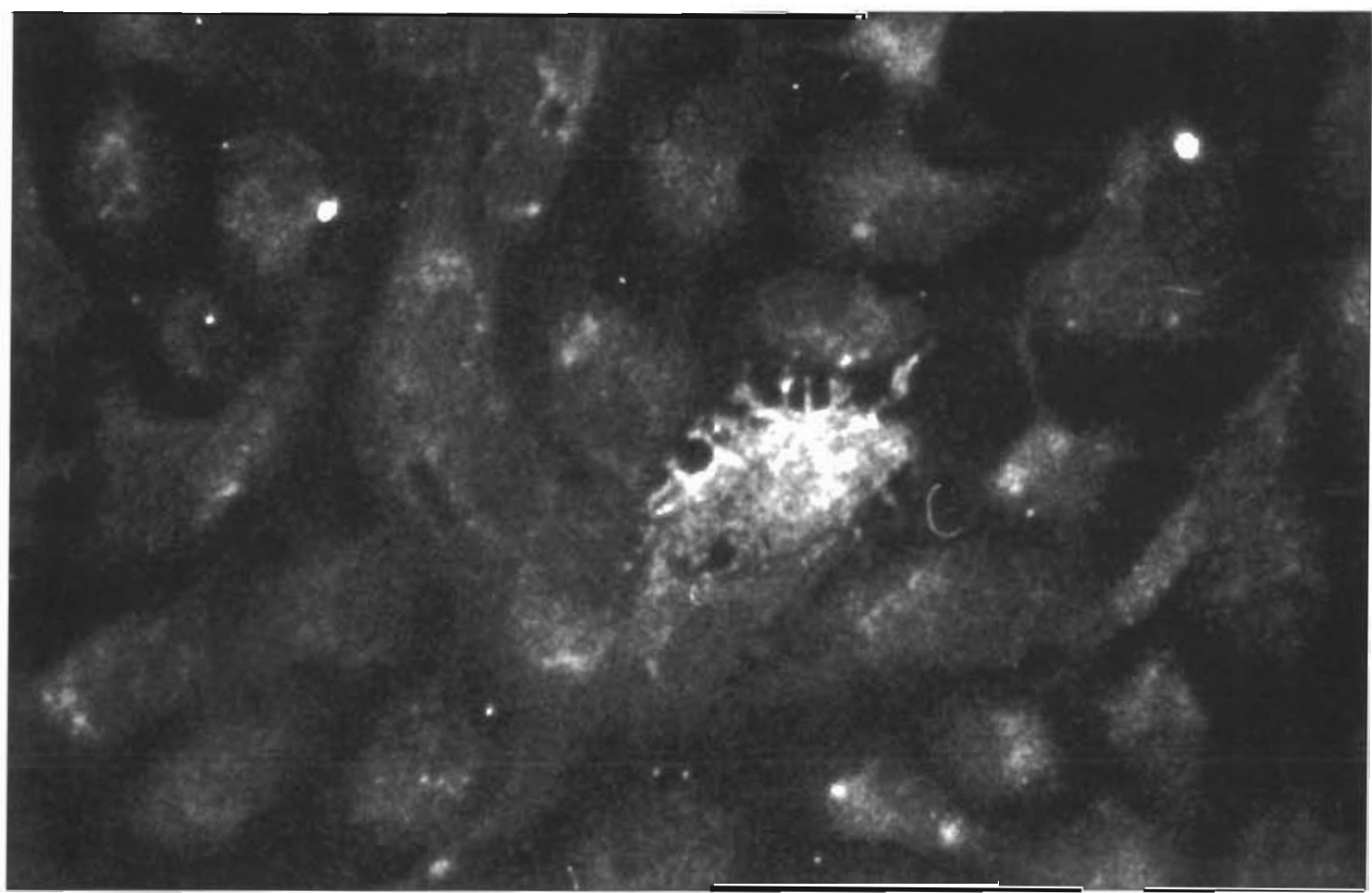

Fig. 3. Immunofluorescence micrograph showing the cross-reaction staining of a perch rhabdovirus-infected EPC cell with rabbit antiserum to virus $903 / 87$ as the primary antibody and TRITC-labelled swine antibody to rabbit Ig as the secondary antibody $(\times 370)$ 
Table 2. Immunofluorescence results with rhabdovirus 903/87 and 2 other fish rhabdoviruses using homologous and heterologous antisera. Reactions are 0 : no reaction; + : weak; ++ moderate; +++: strong

\begin{tabular}{|c|c|c|c|}
\hline \multirow{2}{*}{ Virus } & \multicolumn{3}{|c|}{ Antiserum } \\
\hline & $903 / 87$ & DK 5533 & Perch rhabdovirus \\
\hline $\begin{array}{l}\text { Rhabdovirus } \\
903 / 87\end{array}$ & +++ & + & + \\
\hline $\begin{array}{l}\text { Pike rhabdo- } \\
\text { virus DK } 5533\end{array}$ & 0 & +++ & +++ \\
\hline $\begin{array}{l}\text { Perch rhabdo- } \\
\text { virus }\end{array}$ & + & +++ & +++ \\
\hline $\begin{array}{l}\text { Uninfected } \\
\text { EPC cells }\end{array}$ & 0 & 0 & 0 \\
\hline
\end{tabular}

(Table 2). These reactions rated ' $++t$ ' or ' $t$ ' in Table 2 were the only positive reactions observed in immunofluorescence tests using antiserum to virus $903 / 87$ against the 12 fish rhabdoviruses, or in tests using antisera to the same 12 rhabdoviruses against virus 903/87.

\section{SDS-PAGE}

Comparative analysis of virus isolate 903/87, pike isolate DK 5533 and perch rhabdovirus by SDSPAGE indicated that they all belong to the Vesiculovirus genus of the family Rhabdoviridae (McAllister \& Wagner 1975) (Fig. 4). Small differences were evident among the relative mobilities of the glycoprotein (G) and the phosphoprotein (labeled $N_{s}$ ) of the 3 isolates, whereas the polymerase (L), the nucleoprotein $(N)$ and the matrix protein $(\mathrm{M})$ of the 3 viruses showed identical mobilities (Table 3).

Table 3. Estimated molecular weights (in kilodaltons) of structural proteins of rhabdovirus $903 / 87$ and 2 other fish rhabdoviruses belonging to the genus Vesiculovirus. Molecular weights estimated from the electropherogram shown in Fig. 4

\begin{tabular}{|lccccc|}
\hline Virus & \multicolumn{5}{c|}{ Viral proteins } \\
& $\mathrm{L}$ & $\mathrm{G}$ & $\mathrm{N}_{\mathrm{s}}$ & $\mathrm{N}$ & $\mathrm{M}$ \\
\hline $\begin{array}{l}\text { Rhabdovirus } \\
903 / 87\end{array}$ & 200 & 61 & 51 & 44 & 28 \\
$\begin{array}{l}\text { Pike rhabdovirus } \\
\text { DK-5533 }\end{array}$ & 200 & 60 & 49 & 44 & 28 \\
Perch rhabdovirus & 200 & 62 & 47 & 44 & 28 \\
\hline
\end{tabular}

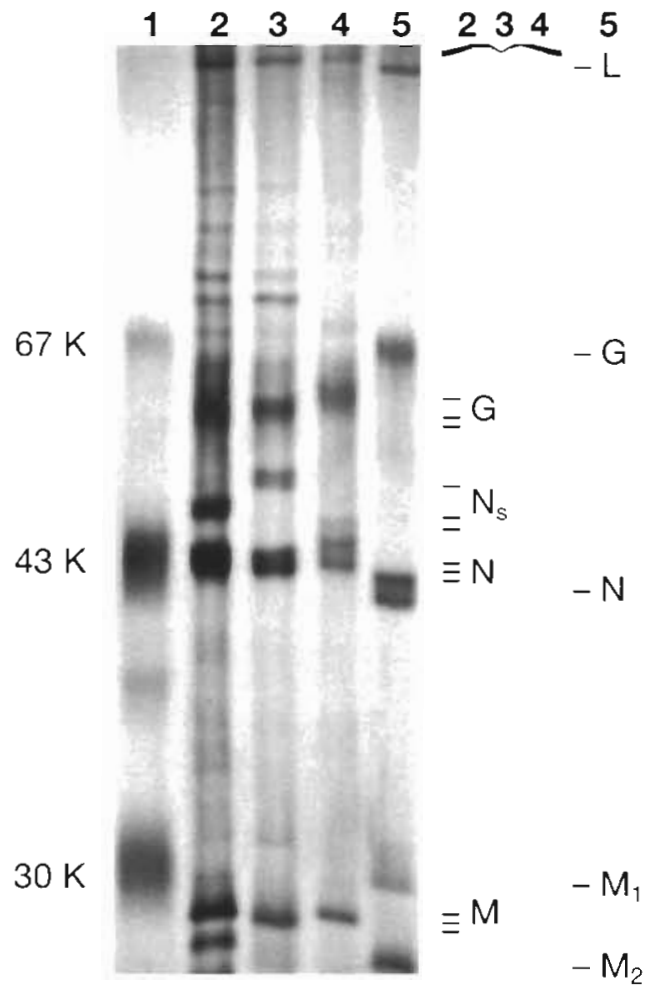

Fig. 4. Electropherogram of purified virus preparations in SDS-PAGE. Lane 1: molecular weight markers (molecular wejghts given in kilodaltons); Lane 2: pike rhabdovirus DK 5533; Lane 3: lake trout rhabdovirus 903/87; Lane 4: perch rhabdovirus; Lane 5: VHS virus. The localization of the structural proteins $G, N_{s}, N$ and $M$ (Lanes 2, 3 and 4) and $G, N, M_{1}$ and $M_{2}$ (Lane 5), respectively, is indicated. L: polymerase. The virus isolates in Lanes 2,3 and 4 belong to the genus Vesiculovirus, while the virus isolate in Lane 5 belongs to the genus Lyssavirus of rhabdoviruses

\section{DISCUSSION}

The cytopathic effects and the morphology of virus $903 / 87$ were typical of those of a rhabdovirus. The dimensions of the virus were measured to $156 \times 65 \mathrm{~nm}$. Based on an average of 15 negatively stained virus particles, Koski et al. (1992) reported the size of the rhabdovirus $903 / 87$ as approximately $170 \times 102 \mathrm{~nm}$. However, because different methods were used for harvesting and purification of the virus and fixation for electron microscopy, the sizes of the virus $903 / 87$ from the 2 studies are not directly comparable.

Koski et al. (1992) reported that in ELISA and serum neutralization tests virus 903/87 appeared to be distinct from VHSV, IHNV, PFR, SVCV, EVEX and perch rhabdovirus, and they concluded that virus $903 / 87$ was a new fish rhabdovirus. Our results confirmed that virus 903/87 was not serologically related to VHSV, IHNV, PFR, SVCV and EVEX nor to an additional 4 rhabdoviruses, i.e. HRV, SHRV, UDRV and carpione 
brown trout rhabdovirus. However, in contrast to the ELISA results obtained by Koski et al. (1992), our data show that the virus $903 / 87$ shares a limited number of antigenic determinants with perch rhabdovirus and also with the recently isolated pike rhabdovirus DK 5533, not examined by Koski et al. (1992). The discrepancy between the results may be due to a higher sensitivity of our immunofluorescence technique compared to the ELISA used by Koski et al. (1992), or due to differences in the cross-reactivity of the antisera. It has been shown that different immunization protocols and different animals may give sera with very different cross-reactivities (Jørgensen 1972, Jørgensen et al. 1989).

The relative mobilities of the virus 903/87, pike rhabdovirus DK 5533 and perch rhabdovirus $A$ and $N$ proteins were very similar, whereas those of $G$ and $N_{S}$ were somewhat different (Fig. 4 and Table 3). The relative mobilities of the proteins $G$ and $N_{s}$ could be used to differentiate the virus $903 / 87$ from the perch rhabdovirus and the pike rhabdovirus DK 5533.

The immunofluorescence test data shown in Table 2 indicate that pike rhabdovirus DK 5533 and perch rhabdovirus are more related to each other than to rhabdovirus 903/87. The strong immunofluorescence cross-reactions between pike rhabdovirus DK 5533 and perch thabdovirus are in agreement with previous findings of Jørgensen et al. (1993). However, more detailed studies of the virus genomes, as well as additional serological examination using techniques such as Western blotting, will be required to further characterize the relationship of rhabdovirus 903/87, pike rhabdovirus DK 5533 and perch rhabdovirus, and to determine to what extent the 3 rhabdoviruses share antigens on their structural proteins.

Since number designations are not overly informative, we suggest that virus $903 / 87$ be renamed the European lake trout rhabdovirus.

Acknowledgements. The authors acknowledge the following persons for generously supplying virus and/or antiserum: Dr K. Wolf, formerly National Fish Health Research Laboratory, Leetown, USA; Dr N. Fijan, formerly University of Zagreb, Zagreb, Croatia; Dr B. Hill, Fish Disease Laboratory, Weymouth, UK; Dr J Castric, Centre National d'Etudes Vétérinaires et Alimentaires. Brest, France; Dr P. de Kinkelin, Institut National de la Recherche Agronomique, Jouy-en-Josas, France; Dr T. Kimura, University of Hokkaido, Hakodate, Japan; Dr E. Neuvonen, National Veterinary Institute, Helsinki, Finland; Dr G. Bovo, Istituto Zooprofilattico Sperimentale delle Venezie, Padua, Italy; and Dr W. Wattanavijarn, Chulagongkorn University, Bangkok, Thailand. We thank Dr James R. Winton (National Fisheries Research Center, Seattle, USA) for valuable comments on the manuscript. H. Björklund acknowledges the Gustaf Packalen Memorial Foundation for financial support.

\section{LITERATURE CITED}

Ahne, W., Jørgensen, P. E. V., Olesen, N. J., Wattanavijarn, W. (1988). Serological examination of a rhabdovirus isolated from snakehead (Ophiocephalus striatus) in Thailand with ulcerative syndrome. J. appl. Ichthyol. 4: 194-196

Amend, D. F., Yasutake, W. T., Mead, R. W. (1969). A hematopoietic virus disease of rainbow trout and sockeye salmon. Trans. Am. Fish. Soc. 98: 796-804

Castric, J., Rasschaert, D., Bernard, J. (1984). Evidence of lyssaviruses among rhabdovirus isolates from European eel (Anguilla anguilla). Annls Virol. (Inst. Pasteur) 135E: 35-55

de Kinkelin, P., Galimard, B., Bootsma, P. (1973). Isolation and identification of the causative agent of 'red disease' of pike (Esox lucius L. 1766). Nature 241: 465-467

Dorson, M., Torchy, S., Chilmonczyk, S., de Kinkelin, P., Michel, C. (1984). A new rhabdovirus pathogenic for perch, Perca fluviatilis L.: isolation and preliminary study. I. Fish Dis 7. 241-245

Fijan, N., Petrinec, Z., Sulimanovic, D., Zwillenberg, L. O. (1971) Isolation of the viral causative agent from the acute form of infectious dropsy of carp. Vet. Arhiv Zagreb 41: 125-135

Fijan, N., Sulimanovic, D., Bearzotti, M., Muzinic, D., Zwillenberg, L. O., Chilmonczyk, S., Vautherot, J. F., de Kinkelin, P. (1983). Some properties of the epithelioma papulosum cyprini (EPC) cell line from carp (Cyprinus carpio). Annls Virol. (Inst. Pasteur) 134: 207-220

Frerichs, G. N., Millar, S. D., Roberts, R. J. (1986). Ulcerative rhabdovirus in fish in Southeast Asia. Nature 322: 216

Jensen, M. H. (1965). Research on the virus of Egtved disease. Ann. N.Y. Acad. Sci. 126: 422-426

Jorgensen, P. E. V. (1972). Freund's adjuvants: their influence on the specificity of viral antisera. Acta pathol. microbiol. scand., Sect. B 80: 931-933

Jørgensen, P. E. V., Olesen, N. J., Ahne, W., Lorenzen, N. (1989). SVCV and PFR viruses: serological examination of 22 isolates indicates close relationship between the two fish rhabdoviruses. In: Ahne, W., Kurstak, E. (eds.) Viruses of lower vertebrates. Springer, Berlin, p. 349-366

Jørgensen, P. E. V., Olesen, N. J., Ahne, W., Wahli, T., Meier, W. (1993). Isolation of a previously undescribed rhabdovirus from pike (Esox lucius). Dis. aquat. Org. 16: 171-179

Kimura, T., Yoshimitzu, M., Gorie, S. (1986). A new rhabdovirus isolated in Japan from cultured hirame (Japanese flounder) (Paralichthys olivaceus) and ayu (Plecoglossus altivelis). Dis aquat. Org. 1: 209-217

Koski, P., Hill, B. J., Way, K., Neuvonen, E., Rintamäki, P. (1992). A rhabdovirus isolated from brown trout (Salmo trutta $\mathrm{m}$. lacustris [L]) with lesions in parenchymatous organs. Bull. Eur. Ass. Fish Pathol. 12(5): 177-180

Laemmli, U. K. (1970). Cleavage of structural proteins during assembly of the head of bacteriophage T4. Nature 227 : $680-685$

McAllister, P. E., Wagner, R. R. (1975). Structural proteins of two salmonid rhabdoviruses. J. Virol. 15: 733-738

Morrissey, J. H. (1981). Silver stain for proteins in polyacrylamide gels: a modified procedure with enhanced uniform sensitivity. Analyt. Biochem. 117: 307-310

Olesen, N. J., Lorenzen, N., Jørgensen, P. E. V. (1991). Detection of rainbow trout antibody to Egtved virus by enzymelinked immunosorbent assay (ELISA), immunofluorescence (IF), and plaque neutralization tests ( $50 \%$ PNT). Dis aquat. Org. 10: 31-38

Wolf, K. Gravell, M., Malsberger, R. G. (1966). Lymphocystis virus: isolation and propagation in centrarchid fish cell lines. Science 151. 1004-1005 